\title{
FIELD AND LABORATORY STUDIES ON INFESTATION OF IMMATURE MANGO FRUITS BY THE PEACH FRUIT FLY, BACTROCERA ZONARA (SAUNDERS)
}

\author{
ALI AHMED AMIN \\ Plant Protection Research Institute, ARC, Dokki, Giza, Egypt \\ (Manuscript received 24August 2016)
}

\begin{abstract}
$\mathrm{T}$ he peach fruit fly, Bactrocerazonata, is one of the fruit flies thatattack mango fruits during maturity and ripening stages causing significant damage. This paper iscontribution for evaluation the role of dropped immature fruits as host of $B$. zonata through sampling dropped mango fruits of different varieties at different stages of maturity in different types of mango cultivations. Also, the study was extended to find an interpretation via laboratory investigation the ability of $B$. zonata females for egg laying on immature mango fruits after abscission for different periods (5, 10 and 15 days) comparing with freshly harvested fruits correlating with biochemical and physical fruit changes after abscission. The results indicated that the immature fruits that on the tree were free of infestation, while the infestation was observed on that were sampled under the trees. Percentages of infestation during the $1^{\text {stseason }}$ (2014) for the early and mid-ripen season varieties were 7.83 and $9.14 \%$, respectively and during the $2^{\text {nd }}$ season(2015) were 5.18 and $5.52 \%$, respectively. The mean no. of obtained pupae/ infested fruit were 7.54 and 12.16 pupae/infested fruit, respectively, and 7.25 and 8.10 pupae / infested fruit, respectively during the second season(2015). The sampled immature fruits of late ripen varieties were free of infestation during the two season. The dropped immature mango fruits were firstly observed to be infested during the $4^{\text {th }}$ week of May and the $1^{\text {st }}$ week of June during the two seasons, respectively. The obtained data revealed that, the immature infestation percentages of early and mid-ripening season varieties were lower in comparison with those sampled during maturity and ripening stages. The laboratory study ensured the preference of $B$. zonata females for egg laying on the fruits that were abscised for 5,10 and 15 days in percentages of 26.67, 46.67 and 53.33\%, respectively, the pupation percentages were $80.85,87.33$ and $89.47 \%$, respectively, adult emergence percentages were 63.16 , 65.59 and $72.18 \%$, respectively, while, the durations of total immature stages that reared on the mentioned abscised fruits were, 18.20, 16.98 and 16.79 days, respectively. The fruit phenological changes including increasing of total soluble sugars, total soluble solids(T.S.S), also reduction of fruit juice acidity and fruit firmness factor may be play an important role in susceptibility of dropped immature mango fruits to the peach fruit fly attacks. Removal of such fruit becomes a necessity for avoiding such risk, also, attention should be paid for following and monitoring the fruit flies status in early times (after fruits setting) instead of later periods during June or July.
\end{abstract}




\section{INTRODUCION}

Egypt has excellent potential for the development of a very prosperous mango (Mangifera indica L.) industry. Egypt produces a significant amount of this fruit close to excellent markets, especially the Arab and European markets. The peach fruit fly, Bactrocera zonata (Saunders) (Diptera: Tephritidae) is one of the most destructive fruit flies that attacking mango fruits, the larvae feed on the pulp of ripe fruits formingtunnels inside them causing a great damage and make fruits unfavorable for marketing and exportation(Saafan, et. al., 2006 and Amin, 2008).

The majority of fruit flies are thought to only oviposit into ripe fruits (Allwood, 1997).The mature and ripen fruits are preferable for the females of fruit fly, who usually choose only mature fruits to lay their eggs (Sarwar et. al., 2014).The green mangoes of Tommy Atkines and Keitt varieties throughout 3 years of field sampling fruits were not infested by the Caribbean fruit fly, Anastrepha suspense (Peña, et. al., 2006).

However, Gikonyo et. al., (2003) reported that wild females of Ceratitiscosyra (Walker) were more attracted to and laid preferentially on greencolouredimmature and turning mangoes than on ripe and yellow mangoes in the naturalenvironment. Also, the very young mangoes, after abscission couldhost Bactrocerainvadens Drew, Tsuruta\& White larvae very early in the season (Vayssières et. al., 2008).

Immature mangoes are distinguished from mature mangoes in that they do not ripe after harvest (Reid, 1992), immature mangoes have a whitish flesh, lack juiciness, and have a sour flavor. Some agricultural practices including over-irrigation, fertilization or mechanical fractions cause falling or dropping premature mango fruits from trees.

In Egypt, no studies were reported to determine if immature mango fruits could represent a risk for the peach fruit fly. The present study was contributed for evaluating the role of dropped immature fruits as host of $B$. zonata through sampling dropped mango fruits of different varieties at different stages of maturity in different types of mango cultivations. Moreover, searching the effect of some biochemical changes of immature fruits after abscission on the completion the life cycle of $B$. zonata to confirm the field studies.

\section{MATERIALS AND METHODS}

\section{A- Field studies:}

\section{The selected experimental orchards:}

This study was conducted at the period from the $1^{\text {st }}$ week of May until the end of August throughout two successive seasons, 2014 and 2015 at Fayoum governorate in two types of mango cultivations: 


\section{1 .The mixed-host orchards:}

The $1^{\text {st }}$ site is located in Ibshway (Senro) district, Fayoum governorate with total cultivated area of 100 feddans including mango, guava, mandarin and pear. Mango trees occupied about $75 \%$ of total cultivated area, Balady varietieswere the most abundant commercial varieties occupying about 30 feddans, followed by Timor, Sediqqe and Owusi varieties ( $\leq 10$ fedanns for each of them), while, the varieties Hendi, Golek, Armanios and Zebdia varied in their cultivated areas ( $\leq 5$ fedanns each). The site $2^{\text {ndis }}$ located atFayoum (Al-Daly) district with total cultivated area of 50 feddans including mango, mandarin and Valencia orange. Mango trees occupied about $70 \%$ of total cultivated area, Sediqqe variety was the most abundant commercial varieties occupying about 20 feddans, followed by Balady and Timor varieties (10 feddans for each of them), while, the varieties Zebdia, Owusi, Keit and Kent differed in their cultivated areas ( $\leq 5$ fedanns for each of them).

\subsection{The mango aggregated orchards:}

The $1^{\text {st }}$ site is located in Ibshway (Abo-ksah) district with total cultivated area of 100 feddans, Balady variety was the most abundant commercial varieties occupying about 50 feddans, followed by Timor,Owusi, Sediqqe and Zebdia varieties (40feddans), while, the late ripen varieties, Keitand Kent were cultivated in areas $\leq 5$ fedanns for each of them. The site $2^{\text {ndis }}$ located in Fayoum (Beni-Saleh) district with total cultivated area of 80 feddans, Balady variety was the most abundant commercial varieties occupying about 40 feddans, followed by Timor, Owusi, and Hendi varieties (35feddans), while, the variety Sediqqe, cultivated in area $\leq 5$ fedanns.

\section{Monitoring of B. zonata populations:}

For monitoring the males of $B$. zonata, six Jackson sticky traps were used for each experimental site. The traps were baited with methyl eugenol as a male lure of B. zonata males and technical malathion as a toxicant agent at a ratio of (4:1), respectively. The traps were hanged at a height of approx., 1.75-2.50 $\mathrm{m}$. and distributed evenly in the tested orchards. Traps were inspected weekly with replacing the sheets and replenished with the mentioned attractant by injecting the cotton wick using medical syringe. The attracted males were counted and the mean catch per trap per day "CTD" was calculated.

\section{Sampling of mango fruits:}

Depending upon mango harvesting season in Middle Egypt region (including Fayoum governorate), mango fruits are assumed to be harvested in July until September (Yahia, 1999). Therefore, the mango fruits were classified into 3 categories; firstly, the fruits of early ripening varieties that could be seasonally harvested during July, including Balady, Hendi, Golek and Armanios; secondly, the mid-ripening varieties that could be harvested during August including, Balady, Timor, 
Sediqqe, Zebdia and Owusi; while, the fruits of last category are assumed to be harvested during September and October, including Keit and Kent varieties.

Throughout the two studied successive seasons (2014 and 2015), for each variety of mango trees, 5 trees were selected and 40 fruits at least representing the cardinal directions of the trees, preferably immature, were weekly inspected. The mentioned fruits were marked to avoid replication of examination. A fruit was considered damaged when a fly ovipuncture or watery spot was visible (Vayssiéres et. al., 2009). The infestation percent damage was determined as ratio of number of infested fruits per total of inspected fruits.

At the period from the $1^{\text {st }}$ week of May till the $3^{\text {rd }}$ week of July, the fallen mango fruit during the successive developmental stages including immaturity, maturity and ripen stages were weekly collected, classified according to their varieties and brought to the laboratory in plastic bags. The fruits were incubated in plastic containers above a layer of sterilized sand $(10 \mathrm{~cm})$. After 3-5 days, the fruits were inspected for assessing infestation percentage, the non-infested fruits were removed. After pupation, the pupae were obtained from sand by sieving counted, and kept in Petri dishes. The emerged adult fruit flies were counted and identified to peach fruit fly or Mediterranean fruit fly (if found).

\section{B- Laboratory studies :}

During the $3^{\text {rd }}$ week of May, 60fruits of immature mango (var. Sediqqe) were pickedand bagged to avoid any infestation. The fruits were grouped whereas twentyfruits were placed over a layer of sand on plastic containers for durations of 5 , 10 and 15 days under room temperature $\left(26 \pm 3.0 C^{\circ}\right)$ to allow following biochemical changes. In addition, five fresh harvested immature fruits were picked to determine some chemical characteristics.

\section{1-Fruit infestation by laboratory reared $B$, zonata flies}

The studies were conducted in the laboratory to determine the ability of $B$. Zonata for depositing eggs inside fruits at different stages of immaturity. Ten fruits were included 5 freshly harvested fruits and 5 fruits that were kept as mentioned above for 5,10 and 15 days, these fruits were exposed for 2 hrs to 200 fertile females of $B$. zonata reared on cage $(40 \times 40 \times 40 \mathrm{~cm})$ in 3 respective times. Hence, the exposed fruits were removed, separated and transferred on smaller plastic containers supplied with a layer of sand to receive pupae and stored under laboratory conditions. The infestation, pupation and emergence percentages were calculated. Also, durations of egg-larval, pupal and total immature stage were estimated for the individuals of each infested fruit.

\section{Determination of some chemical constituents of fruit:}

Five fruits of each group that were kept under room temperature for 5, 10 and 15 days apart of the tree were transferred to the Central Laboratory of Chemical, 
Biological and Microbiological Unit, Horticulture Research Institute, Agriculture Research Center (ARC) to determine some chemical phonological characteristics. The assessed chemical characteristics included total soluble sugars, T.S.S. (Total soluble solids $\%$ of the fruit juice), Total acidity (TA), fruit moisture (water content $\%$ ) and fruit firmness.

For assessing total soluble sugar, a known weight of the dried ground sample was taken to extract soluble sugars and boiled in $100 \mathrm{ml}$. of $70 \%$ neutral ethanol for 6-8 hrs under reflux. The extract was filtered and the ethanol was removed by vacuum distillation. The residue was clarified by the leading and deluding method as described before. The last solution was filtered, completed to a known volume and subjected for colorimetric determination (expressed as glucose) of total soluble sugars and reducing ones (Tanaka et. al., 1975).

Total acidity as gm of unhydrous citric acid was determined and estimated per $100 \mathrm{ml}$ fruit juice, for assessing water content of fruits, the fresh fruits were weighted, then oven dried at $70{ }^{\circ} \mathrm{C}$ until constant weight and average fruit fresh and dry weights (gm) was determined (A.O.A.C., 1990). Fruit juice total soluble solids percentage (T.S.S. \%) was determined using Carl Zeiss ${ }^{\circledR}$ hand refract meter. Fruit firmness was determined by using Penetrometer (fruit pressure tester, mango model), Model FT327.

\section{C : Statistical anaylsis :}

The statistical analysis was done as one way ANOVA and means separated was conducted by using L.S.D. at the probability of $5 \%$ (Costat, 1990).

\section{RESULTS AND DISCUSSION}

\section{A- Population monitoring:}

Fig.(I) shows the population of $B$. zonata on two different types of mango tree cultivations at Fayoum governorate during two successive seasons 2014 and 2015, particuerly the period from May to the end of August, coinciding devolpmental stages of mango fruits.

For the $1^{\text {st }}$ season (2014), the data illustrated in Fig. (1) shows various densities of $B$. zonata population in the mentioned two types of mango cultivations. The mixed fruit cultivation was more attractive for $B$. zonata. The trend of $B$. Zonata CTD values started with 0.67 and 2.00 flies/trap/day on the $1^{\text {st }}$ week of May for the aggregated mango orchards and the mixed-hosts orchard, respectively. The highest CTD value was recorded on the mango aggregated orchards (13.67 flies / trap / week) on the $5^{\text {th }}$ week of July, while the highest CTD on the mixed-hosts cultivation was 18.67 flies / trap / week on the $3^{\text {rd }}$ week of August, respectively. 

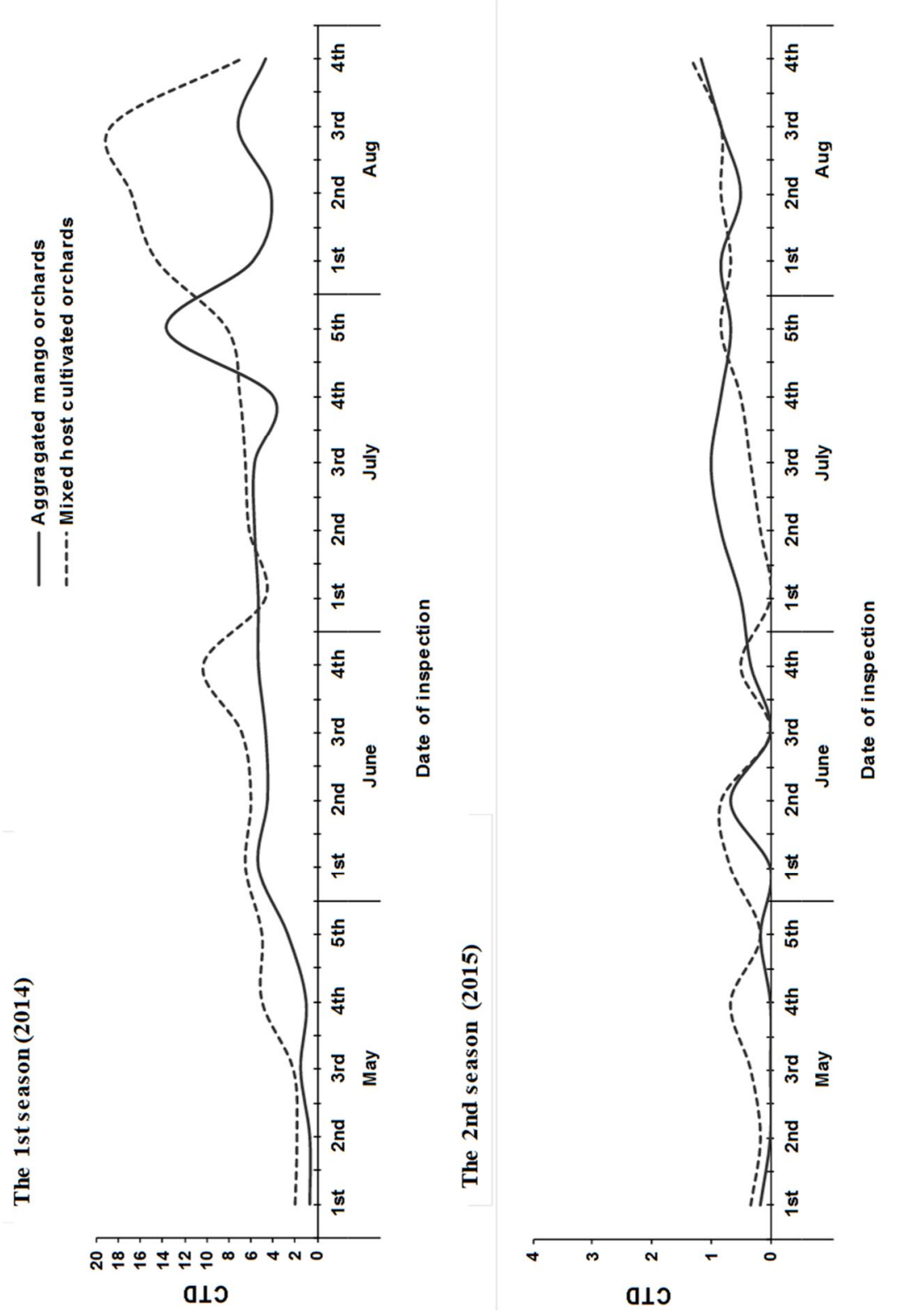

亭

茫

운

ชั

产

F

量寅

든 등

ठ ㅠㅛ

인

它

4

Ð

$\sum_{i}$

$+\frac{\pi}{\circ}$

(ํ)

幽

등

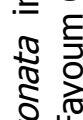

ऽิ

$\infty$

to

ญ 흠

든

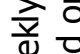

ఖ

들 일

등 음

䒕

ชั

$\rightarrow$

문 
For the $2^{\text {nd }}$ season (2015), the abundance of $B$. zonata population was relatively lower when compared with the previous season. Efforts of the National Area Fruit Flies Eradication Program may be suppressed the

population of $B$. zonata through applications of male annihilation technique. However, B. zonata was more abundant on the mixed-hosts fruit cultivations than the other type. The trend of CTD values started with 0.17 and 0.33 fly/trap/day on the $1^{\text {st }}$ week of May for the aggregated mango orchards and the mixed-hosts orchard that containing mango, respectively. Notably, on the aggregated mango orchards, the traps indicated the absence of $B$. zonata males during some weeks of May and June coinciding with mango fruit immaturity. Applications of male annihilation technique that were carried out bythe National Area Fruit Flies Eradication Program may be the main responsible for such absence of $B$. zonata male flies. The highest mean of CTD values was observed on the mixed-hosts orchards that containing mango ( 1.17 flies/trap/day) on the $4^{\text {th }}$ week of August, On the mixed-host orchards, the highest CTD value was observed (1.33 flies / trap / week) on the $4^{\text {th }}$ week of August.

With a careful view, B. zonata had somewhat the same tend of population fluctuations during the two study seasons. $B$. zonata density was higher in the $1^{\text {st }}$ season (2014) than that on the $2^{\text {nd }}$ season (2015). Previous results indicted the impact role of hosts diversity and availability such as peach, apricot, mandarin and Valencia orange which its fruits are available in ripening stage earlier than mango fruits. Such host range may support the $B$. zonata flies to rebuild new generations (Saafan et. al., 2006, Amin, 2008, and Amin \& Saafan 2013). The emerged flies from the mentioned fruits maybe are supposed to attack mango fruits available for infestation as possible. Drew and Hooper (1983) stated that females with mature ovaries tend to remain or very near fruiting host plants so long as the fruit is acceptable for egg laying. If the plants are non-host or hosts with low quality fruit, the mature females either arrive in low numbers and/or emigrate rather rabidly.

\section{B- Infestation percentages of $B$. zonata:}

Concerning the infestation percentages, the field observations revealed that, all the inspected immature fruits that were on the tree were found to be free of infestation by $B$. zonata during all the studied period of the two seasons. The collected immature mango of fallen fruits that sampled from the orchards of the aggregated mango, only were not infested by $B$. zonata during all the studied two seasons. Besides, absence of fruit flies infestation symptoms, no emerged adults were recorded from all samples of various varieties during immaturity stage. While, the 
other sampled immature fruits that were collected from mixed-hosts orchards varied as shown in Table (1).

\section{1-The $1^{\text {st }}$ season (2014):}

Data of Table (1) indicates that mean infestation percent of immature mango fruits of early ripening varieties that collected under the trees were with $7.83 \%$,while, the mentioned varieties differed in their infestation rates by $B$. zonata. Balady varieties were the most infested fruits (8.58\%) followed by Hendi $(6.56 \%)$, Golek $(5.58 \%)$ and Armanios (4.17\%)varieties.

The mean no. of obtained pupae/fruit infested early immature fruits was 7.54, while, the highest mean no. of obtained pupae/ infested fruit was for Armanios variety (18.00 pupae / infested fruit), and the lowest one was observed obtaining from Balady varieties (6.69 pupae/ infested fruit). The emergence percentage of the early ripen varieties ranged $72.73-88.89 \%$. This data may explain the relationship between sensitivity of different mango varieties to infestation with $B$. zonata and consequently the number of attracted flies into traps. Concerning the maturity and ripening stages of early ripen varieties; all the mango varieties were observed to increase in their infestation levels. It should be notable that the mean no. of obtained pupae was higher than that recorded during immaturity stage. Data in Table (2) revealed that, immature mango fruits were observed to be infested during the $4^{\text {th }}$ week of May excepting Golek fruits variety which was infested during the $5^{\text {th }}$ week of May.

Concerning the mid-season ripening mango varieties, the mean infestation percent was $9.14 \%$, Balady fruits recorded the highest infestation $(12.79 \%)$, followed by Sediqqe, Timor and Zebdia (9.68, 7.14 and $6.67 \%$ respectively), while Owusi immature fruits were free of infestation (Table 1). The mean no. of obtained pupae/infested fruit was 12.16, Sediqqe fruits produced the highest mean no. of pupae (13.67 pupae/infested fruit). Routinely, the infestation \% of mid-season ripening varieties increased during maturity and ripening stages. Subsequently, the mean no. of obtained pupae increased for all varieties comparatively to that obtained during immaturity stage.

Table (2) revealed that the start of infestation of immature mango fruits of some Balady varieties and Sediqqe varieties (mid-season ripening varieties) were observed during the $5^{\text {th }}$ week of May. The sampled fruits of Keitt and Kent as late ripening varieties were observed to be absolutely free of infestation. 
Table 1. Mean infestation \% of dropped immature mango fruits of different varieties by $B$. zonata, mean no. of obtained pupae/ infested fruit and emergence \% at Fayoum governorate during seasons of 2014 and 2015.

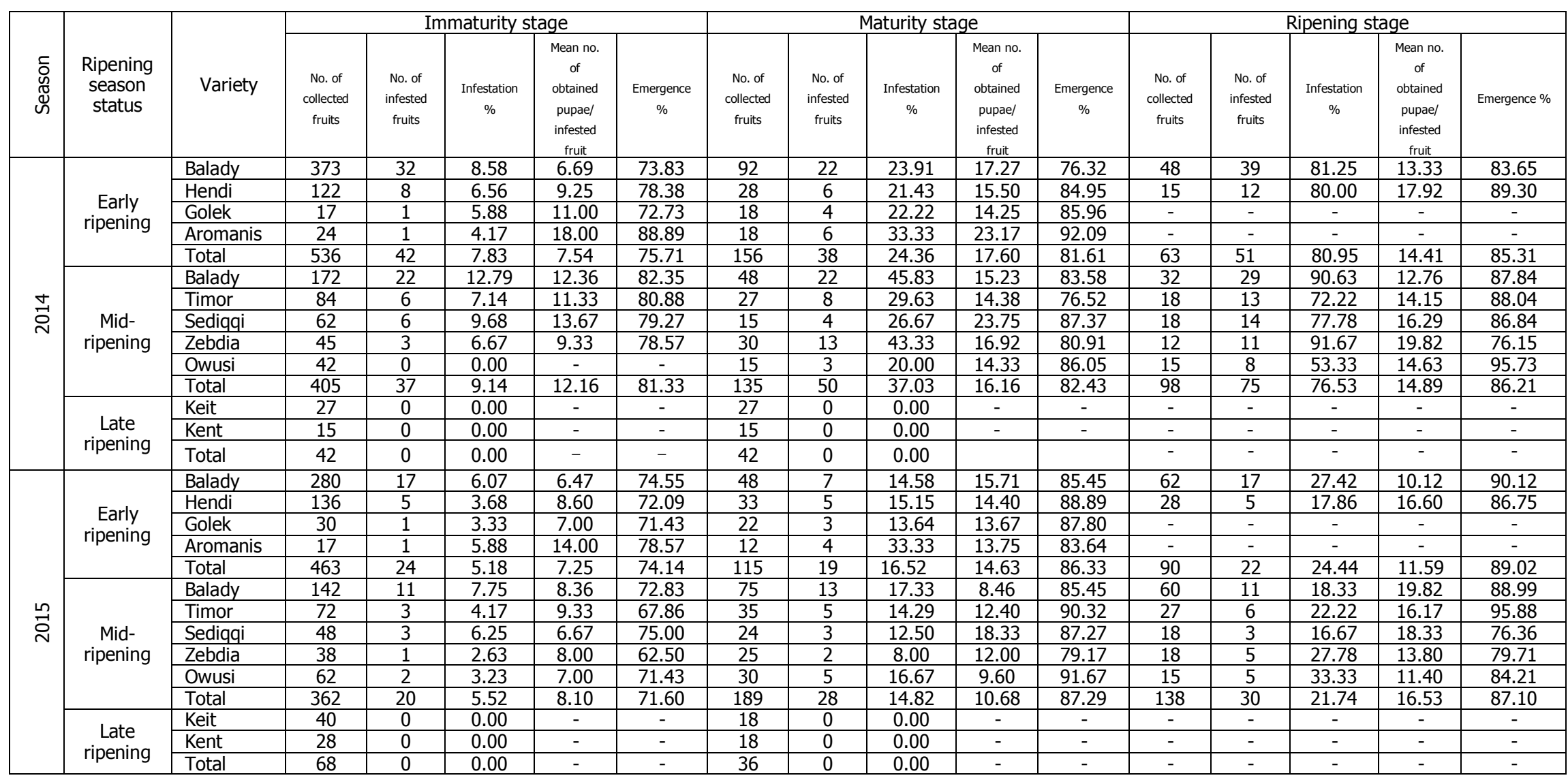




\section{2- The $2^{\text {nd }}$ season (2015):}

The percentage of infestation of immature mango fruits of early ripening varieties by $B$. zonata, was $5.18 \%$ (Table 1 ). Regarding the varieties infestations, Baladyvarieties were the most infested $(6.07 \%)$ followed by Armanios (5.88\%), Hendi (3.68\%) and Golek(3.33\%) varieties. The mean no. of obtained pupae/infested fruit was 7.25, the highest mean no. of pupae/ infested fruit was obtained from Armanios variety (14.00 pupae / infested fruit), while the lowest one was observed from Balady varieties (6.47 pupae/ infested fruit). The emergence percentage ranged between $71.43-78.57 \%$.

Concerning the maturity and ripening stages of early ripening varieties, all the mango varieties were observed to increase in their infestation levels. It should be notable that the men no. of obtained pupae was higher than that recorded during immaturity stage. Data in Table (2) revealed that immature mango fruits of Balady and Armanios varieties were observed to be infested during the $1^{\text {st }}$ week of June.

Table 2. Date of infestation of dropped immature fruits of some mango varieties at Fayoum governorate during the two successive seasons 2014 and 2015.

\begin{tabular}{|c|c|c|c|c|c|c|c|c|c|c|c|c|}
\hline \multirow{2}{*}{ Season } & \multirow{2}{*}{\multicolumn{2}{|c|}{ Varieties }} & \multicolumn{3}{|c|}{ May } & \multicolumn{4}{|c|}{ June } & \multicolumn{3}{|c|}{ July } \\
\hline & & & $3^{\text {rd }}$ & $4^{\text {th }}$ & $5^{\text {th }}$ & $1^{\text {st }}$ & $2^{\text {nd }}$ & $3^{\text {rd }}$ & $4^{\text {th }}$ & $1^{\text {st }}$ & $2^{\text {nd }}$ & $3^{\text {rd }}$ \\
\hline \multirow{11}{*}{2014} & \multirow{4}{*}{ Earlyripening } & Balady & - & + & + & + & & & & & & \\
\hline & & Hendi & - & + & + & + & & & & & & \\
\hline & & Golek & - & 一 & + & + & & & & & & \\
\hline & & Aromanis & - & + & + & + & & & & & & \\
\hline & \multirow{5}{*}{$\begin{array}{l}\text { Mid-season } \\
\text { ripening }\end{array}$} & Balady & - & 一 & + & + & + & & & & & \\
\hline & & Timor & - & - & - & + & + & & & & & \\
\hline & & Sediqqi & - & - & + & + & + & & & & & \\
\hline & & Zebdia & - & 一 & - & 一 & + & + & & & & \\
\hline & & Owusi & - & - & - & - & - & + & + & & & \\
\hline & \multirow{2}{*}{ Lateripening } & Keitt & - & 一 & - & - & - & - & - & - & - & - \\
\hline & & Kent & - & 一 & - & - & - & - & - & 一 & - & 一 \\
\hline \multirow{11}{*}{2015} & \multirow{4}{*}{ Earlyripening } & Balady & - & - & - & + & + & & & & & \\
\hline & & Hendi & - & 一 & - & - & + & + & + & & & \\
\hline & & Golek & - & - & - & - & + & + & + & & & \\
\hline & & Aromanis & - & - & - & + & + & + & & & & \\
\hline & \multirow{5}{*}{$\begin{array}{l}\text { Mid-season } \\
\text { ripening }\end{array}$} & Balady & - & 一 & - & - & + & & & & & \\
\hline & & Timor & - & - & - & - & - & + & + & & & \\
\hline & & Sediqqi & - & - & - & - & + & + & & & & \\
\hline & & Zebdia & - & 一 & - & - & - & - & + & & & \\
\hline & & Owusi & - & 一 & - & - & - & - & + & & & \\
\hline & \multirow{2}{*}{$\begin{array}{l}\text { Late } \\
\text { ripening }\end{array}$} & Keitt & - & 一 & - & - & - & - & - & - & - & - \\
\hline & & Kent & - & 一 & - & - & - & - & 一 & 一 & - & 一 \\
\hline
\end{tabular}

- Sampled fruits are not infested by $B$. zonata+Sampled fruits are infested by $B$. zonata 
Among the mid-season ripening mango varieties, someBalady fruits recorded the highest infestation $(7.75 \%)$, followed by Sediqqe $(6.25 \%)$, Timor(4.17), Owusi(3.23), and Zebdia (2.63\%).The mean no. of obtained pupae/infested fruit was 12.16,while, Timor fruits produced the highest mean no. of pupae (9.33 pupae/infested fruit). During maturity and ripening stages, subsequently, the infestation rates and the mean no. of obtained pupae increased for all varieties comparatively to that obtained during immaturity stage. The start of infestation of mid-season ripening mango fruits of Balady and Sediqqe varieties was observed during the $2^{\text {nd }}$ week of June (Table 2), while, in Timor, infestation started on the $3^{\text {rd }}$ week of June and in case of Zebdia and Owusi, the infestation started at the $4^{\text {th }}$ week of June. The sampled fruits of Keitt and Kent as late ripening varieties were observed to be absolutely free of infestation.

Generally, the obtained results indicated that the infestation \% of immature mango fruits may increase under higher levels of population density of $B$. zonata, the reduction of infestation of the $2^{\text {nd }}$ season (2015) maybe due to low population density of $B$. zonata when compared with $1^{\text {st }}$ season (2014), particularly, correlated by mixed-host cultivations which supporting the favorable conditions for overlapping $B$. zonata generations. The levels of infestation depend on the surrounding host plants and agro-ecological conditions of the locality (Sarwar et. al., 2014). The mean numbers of pupae of $B$. zonata obtained from mature and ripe fruits of mango were higher than those obtained from immature fruits, thus indicating success of $B$. zonata immature stages to complete their life cycle.

The non-infestation of immature fruits on the tree may due to the contraction of immature fruit against female ovipositor stings.As soon as this occurs, latex leaks from the punctured wounds could be observed on the skin of fruit(Sarwaret. al.,2014).Differences among cultivars were suggested to be caused by differences in toxic chemicals, nutrients, or resin ducts (Peña \& Moyhuddin, 1997).The green mangoes (Tommy Atkines and Keitt varieties) throughout 3 years of field sampling fruits were not infested by the Caribbean fruit fly, A.suspensa (Peña et. al., 2006).

All dropped immature fruits of sampled varieties can be infested by the $B$. zonata excluding some late ripening varieties, thus is interpreted by availability of other early and mid-season ripening mango varieties as a mature and ripen status which are preferable for the females of fruit fly that usually choose only mature fruits to lay their eggs (Sarwar et. al.,2014). Also, the mature mangoes served as abetter substrate for development of the Caribbean fruit fly, A. suspense (Hennessey \& Schnell, 2001). 
The obtained results are in agreement with those previously stated by Vayssières et. al., 2008 and Diatta, et. al., 2013 who revealed that, the immature abscised fruits of mango could host $B$. Invadens larvae very early in the season beside infesting green and ripe host fruits. Also, immature mangoes supported from 2-59\% of the emergence of $A$. suspense compared with mature fruits (Hennessey \& Schnell 2001).Moreover, in certain cases, some immature young fruits are also attacked, which may fall to ground from the host tree (Sarwar et. al., 2014).

\section{B-Laboratory studies:}

\section{1-Infestability of $B$. zonata}

As shown in Table (3), under forced infestation, the freshly harvested fruits during immaturity stage were not infested by the fertile females of $B$. zonata comparing to those fruits that exposed in same time.While, the abscised immature fruits were infested in various percentages, the fruits that were abscised for 15 and 10 days were significantly the highest ones (53.33 and $46.67 \%$, respectively), while, the fruits that abscised for 5 days were the lowest one (26.67\%). The mean numbers of pupae of $B$. zonata obtained from the fruits that were abscised for 15 and 10days fruits of mango (16.63and 15.14pupae per fruit, respectively)were significantly higher than those obtained from green fruits (11.75 pupae per fruit).

As shown in Fig. (2), the egg-larval stage varied significantly in durations when rearing on the different stages of abscessed immature mango fruits under room temperature. The egg-larval stage averaged 9.12, 9.24 and 10.38 days, while the pupal stage averaged 7.67, 7.74 and 7.82days, with total duration of $16.79,16.98$ and 18.20 days for the immature mango fruits that abscised for 15,10 and 5 days, respectively. In the same manner, the pupation percentages were significantly differed, whereas averaged89.47, 87.73 and $80.85 \%$ for the immature mango that abscised fruits for 15,10 and 5 days, respectively. The percentages of emergence were significantly differed for the immature mango fruits that detached for 15,10 and 5 days averaging $72.18,65.59$ and 63.16 days, respectively. 
Table 3.Infestability of caged $B$. zonata females for egg laying on freshly harvested fruits and abscised immature fruits for 5,10 and 15 days.

\begin{tabular}{|c|c|c|c|c|c|c|c|}
\hline \multicolumn{2}{|c|}{ Immature fruits status } & \multirow{2}{*}{$\begin{array}{c}\text { No. of } \\
\text { exposed } \\
\text { fruits }\end{array}$} & \multirow{2}{*}{$\begin{array}{c}\text { No. of } \\
\text { infeste } \\
\text { d fruits } \\
0\end{array}$} & \multirow{2}{*}{$\begin{array}{c}\text { Infestati } \\
\text { on } \%\end{array}$} & \multirow{2}{*}{$\begin{array}{c}\text { Mean } \\
\text { no. of } \\
\text { obtained } \\
\text { pupae/ } \\
\text { infested } \\
\text { fruit } \\
\text { - }\end{array}$} & \multirow{2}{*}{$\begin{array}{c}\text { Pupation } \\
\text { \% } \\
\text { - }\end{array}$} & \multirow{2}{*}{$\begin{array}{c}\text { Emerge } \\
\text { nce \% } \\
\text { - }\end{array}$} \\
\hline After 5 & Freshly harvested fruits & & & & & & \\
\hline days & Abscised fruits & 15 & 4 & $26.67 b$ & $11.75 b$ & $80.85 b$ & $63.16 \mathrm{~b}$ \\
\hline \multirow{2}{*}{$\begin{array}{l}\text { After } 10 \\
\text { days }\end{array}$} & Freshly harvested fruits & 15 & 0 & 00.00 & - & - & - \\
\hline & Abscised fruits & 15 & 7 & $46.67 a$ & $15.14 a$ & $87.73 a$ & $65.59 b$ \\
\hline \multirow{2}{*}{$\begin{array}{c}\text { After } \\
15 \text { days }\end{array}$} & Freshly harvested fruits & 15 & 0 & 00.00 & - & - & - \\
\hline & Abscised fruits & 15 & 8 & $53.33 a$ & $16.63 a$ & $89.47 a$ & $72.18 a$ \\
\hline
\end{tabular}

Means followed by the same latter vertically are insignificantly varied.

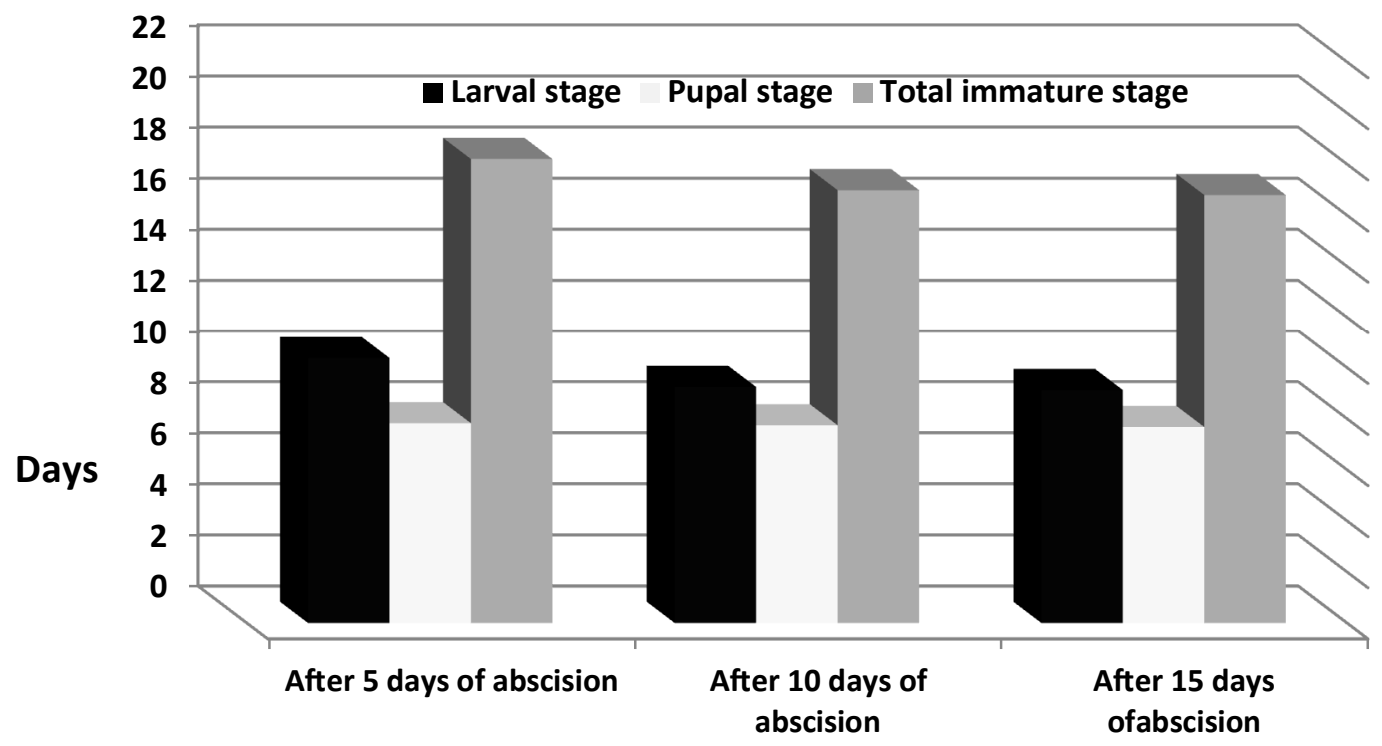

Fig. 2. Durations of $B$. zonata immature stages rearing on the abscised immature mango fruits under room temperature .

\section{2-Chemical changes of abscised fruits:}

Table (4) presents the changes of most important biochemical characteristics that may be mainly involved during maturity and ripening stages of mango fruits including, total soluble sugars, T.S.S, TA, fruit moisture (water content\%) and fruit firmness. The total sugars increased gradually in significance from $2.01 \mathrm{~g} / 100 \mathrm{~g}$ at the immature harvested fruits to the highest one $3.79 \mathrm{~g} / 100 \mathrm{~g}$ for the fruits that picked tree for 15 days. TSS increases slightly at the mature-green stage. 
T.S.S content of mango gradually increased gradually from $3.70 \%$ in the freshly harvested fruits to highest one $5.60 \%$ for fruits that picked from trees for 10 days. Quintana et. al., 1984 reported that TSS of mango increased gradually up to maturity. TA of freshly harvested mango decreased from $0.26 \%$ to $0.11 \%$ in fruits that picked from tree for 10 days. In general, young fruit contain more acids, that declined throughout maturation until ripening due to their conversion to sugars (gluconeogenesis).

Table 4. Fruit characteristics of immature mango fruits including freshly harvested fruits and abscised fruits for 5, 10 and 15 days under room temperature .

\begin{tabular}{|c|c|c|c|c|c|}
\hline The fruit status & $\begin{array}{c}\text { Total } \\
\text { sugars } \\
(\mathrm{g} / 100 \mathrm{~g})\end{array}$ & $\begin{array}{c}\text { T.S.S } \\
\%\end{array}$ & $\begin{array}{c}\text { Moisture } \\
\%\end{array}$ & $\begin{array}{c}\text { Acidity } \\
\%\end{array}$ & $\begin{array}{c}\text { Firmness } \\
\mathrm{Lb}^{\text {inch }}{ }^{2}\end{array}$ \\
\hline Freshly harvested fruits & $2.01 \mathrm{c}$ & $3.70 \mathrm{c}$ & $82.96 \mathrm{~b}$ & $0.26 \mathrm{a}$ & $35.80 \mathrm{a}$ \\
\hline After 5 days of abscission & $3.19 \mathrm{~b}$ & $5.50 \mathrm{~b}$ & $85.42 \mathrm{ab}$ & $0.19 \mathrm{~b}$ & $33.80 \mathrm{~b}$ \\
\hline After 10 days of abscission & $3.32 \mathrm{~b}$ & $5.60 \mathrm{a}$ & $86.16 \mathrm{a}$ & $0.12 \mathrm{c}$ & $32.00 \mathrm{bc}$ \\
\hline After 15 days of abscission & $3.79 \mathrm{a}$ & $5.80 \mathrm{ab}$ & $87.89 \mathrm{a}$ & $0.11 \mathrm{c}$ & $31.80 \mathrm{c}$ \\
\hline
\end{tabular}

Means followed by the same latter vertically are insignificantly varied.

Fruit firmness declined from $35.80 \mathrm{Lb} /$ inch $^{2}$ in the freshly harvested fruits to $31.80 \mathrm{Lb} /$ inch $^{2}$ in the fruits that detached for 15 day $\mathrm{s}$ (Table 4). Changes in average firmness were also correlated with changes in acidity and T.S.S of the fruit during ripening (Mizrach et. al., (1997).The change of water content was not effective comparatively to other factors, however, significant variations were observed among the fruits of the three treatments. Moisture percentage of different varieties significantly differed and reported more than $80 \%$ in all varieties for the harvested mango fruits after 10,13,16 and 19 weeks after flowering in all stages of fruit development (Ueda et. al., 2000).

To understand the ability of $B$. zonata females for egg laying on abscised immature fruits, in same time its failure to attack the immature fruits that either on the trees or that freshly harvested and that were exposed on the rearing cages, fruit firmness may be play an important role for facilitation the penetration of female ovipositor through fruit skin. The fruits that abscised for 15 days of tree had the lowest mean of fruit firmness; also, they were the most infested fruits. In other words, the gradual decline of fruit firmness correlated in positively with $B$. zonata infestation. Also, the freshly harvested fruits that had the highest mean of fruit firmness were not infested in all respective exposing comparing to others abscised fruits. Changes in average firmness were also correlated with changes in acidity and T.S.S of the fruit during ripening (Mizrach et. al., (1997). Cell wall degradation is the 
major factor that causes softening of several fruits. Fruit firmness played an important role in oviposition strategies of female Anastrepha ludens (Loew), that laying larger egg clutches into unripe fruit than ripe fruit (Diaz-Fleischer \& Aluja, 2003).

Commonly, the biochemical changes of abscised immature fruits may support the $B$. zonata individuals to complete its life cycle on the abscised immature fruits. Rattanapun et. al., 2009 indicated that the changes in total soluble solids, T.S.S, and skin toughness correlate with changing host use across the ripening stages of two mango varieties when infested by $B$. dorsails. Therefore, the physical change in skin texture and fruit firmness reflects the biochemical changes of starch accumulation, $\mathrm{T}$. S. S, reduction of acidity.

The obtained results are so similar to that reported by Diattaet.al., 2013 who indicated that, the lowest mean numbers of $B$. invadens, pupae were obtained from green fruits on fruit species belonging to three families and many more pupae were counted in mature fruits. In addition, the mango fruit fly Ceratitis cosyra (Walker),was attracted to and oviposited preferentially on immature and mature green than ripe yellow mango fruits in the field (Gikonyo et. al., 2003).Contrary to them, Peña et. al., 2006 revealed that the green mango fruits of "Keitt" variety showed a very low rate of larval emergence of the Caribbean fruit fly, $A$. suspense under very high fly population pressure under laboratory cage infestation, thus, indicating the fruits are poor host conditionally.

It could be concluded that, success of $B$. zonata for infesting and completing its life cycle through dropped immature mango fruits saves an advantage for $B$. zonata to increase its population under field conditions. The infestation rate of abscised immature mango fruits is seemed to be affected by some factors including the availability of mixed-host orchards, higher density of fly population and the longevity of fruit abscission under trees. The mixed-host orchards especially those containing early ripe mango varieties present a favorable environment that can support strongly $B$. Zonata fertile females under absence of suitable host in ripe stage before the mangoes reach the turning stage. The phonological changes including chemical and physiological changes could be considered the major factors that play an important role in susceptibility of dropped immature mango fruits to fruit fly attacks. Removal of such fruit becomes necessary for avoiding such risk. Also, attention should be paid for following and monitoring the fruit flies status in early times ( $1^{\text {st }}$ week of May at least) instead of later periods during June or July. 


\section{REFERENCES}

1. A. O. A. C. (Association of Official Analytical Chemists).1990. Methods of analysis $13^{\text {th }}$ ed., Association of official agricultural chemical. Washington D.C., U.S.A.

2. Allwood, A. J. 1997. Biology and ecology: Prerequisites for understanding and 500 managing fruit flies (Diptera: Tephritidae). In Management of Fruit Flies in the Pacific: A regional symposium. ACIAR Proceedings No. 76 (eds. Allwood A. J. \& Drew R. A. I.), pp. 95-101. Aust. Centre Intern. Agric. Res. Canberra.

3. Amin, A. A. 2008. Ecological and biological studies on the peach and Mediterranean fruit flies in Fayoum governorate. Ph. D. Thesis, Fac. Agric., Fayoum University. 225 pp.

4. Amin, A. A. and M. H. Saafan 2013. Date palm fruits as a potential host of the peach and Mediterranean fruit flies in Fayoum governorate. Egypt. J. Agric. Res., $91(1)$.

5. CoStat Software. 1990. Microcomputer program analysis Version 4.2, CoHortSofware, Berkeley, CA.

6. Diatta, P.; J. Y. Rey; J. F. Vayssieres; K. Diarra; M. Coly; M. Lechaudel; I. Grechi; S. Ndiaye and O. Ndiaye. 2013. Fruit phenology of citrus, mangoes and papayas influences egg-laying preferences of Bactrocerainvadens (Diptera: Tephritidae). Fruits. 68 (6) 507-516.

7. Diaz-fleischer, F.andM. Aluja. 2003. Clutch size in frugivorous insects as a function of host firmness: the case of the tephritid fly Anastrephaludens. Ecol.Entomol. 28(3): 268-277.

8. Drew, R. A. I. and G. H. S.Hooper.1983. Population studies of fruit flies in southeast Queensland. Oecologia,56: 153-159.

9. Gikonyo, N.K.; S.A. Lux and P.S.Nemeye. 2003.Variation in Volatiles from Fruits of Mango and Marula Attractive to the Mango Fruit Fly, Ceratitiscosyra(Walker). East and Central African Journal of Pharm. Sci. 6:3-8

10. Hennessey, M. K., and R. J. Schnell.2001. Resistance of immature mango fruits to Caribbean fruit fly (Diptera: Tephritidae). Florida. Entomol.84(2), 318-319.

11. Mizrach, A.; U. Flitsanovand Y. Fuchs. 1997.Anultrasonic nondestructive method for measuring maturity of mango fruit. Trans. ASAE 40(4): 1107-1111.

12. Peña, J. E. and A. I.Mohyuddin. 1997. Insect pests. In: The mango - botany, production and uses (ed. R.E. Litz). CAB International, Oxfordshire, UK, pp. 327362.

13. Peña, J. E.; W. P. Gould; M. K. Hennessey; G. J. Hallman and Crane J. H. 2006. Laboratory and field infestation studies on immature green 'Tommy Atkins' and 
'Keittt' mangoes to determine host status to the Caribbean fruit fly (Diptera: Tephritidae). Proc. Florida State Hort. Soc. 119: 16-20.

14. Quintana, E. G.; P. Nanthachai; H. Hiranpradit; D. B. Mendoza JR. and S. Ketsa. 1984. Changesin mango during growth and maturation: Growth and development of mango, In : D.B. Mendoza, R.B.H. Wills (Eds.), Mango fruit development, postharvest physiology and marketing in ASEAN, ASEAN Food Handling Bureau, Kuala Lumpur, Malaysia, pp. 21-27.

15. Rattanapun, W.; W. Amornsak, and A. Clarke. 2009.Bactrocera dorsalis Preference for and performance on two mango varieties at three stages of ripeness. Entomol. Exp. Appl., 131. pp. 243-253.

16. Reid, M. S.1992. Maturation and maturity indices, p.21-28. In A. A. Kader (ed.). Postharvest technology for horticultural crops. Univ. California Div. Agric. and Natural Resources Publ. 3311.

17. Saafan, M.H.; S. M. Foda and A. A. Amin. 2006. Ecological studies on fruit flies on different hosts at Fayoum governorate, Egypt. Egypt. J. Agric. Res. 84(2): 323-336

18. Sarwar, M.; M. Hamed; M. Yousaf and M. Hussain. 2014.Surveillance on population dynamics and fruits infestation of Tephritid fruit flies (Diptera: Tephritidae) in mango (Mangiferaindica L.) orchards of Faisalabad, Pakistan. Int. J. Sci Res. Environ. Sci 2, 113-119.

19. Tanaka, M.; D. L. Thananunku; T. Lee and C. O. Chichester. 1975. Asimplifiedmethod for the quantitative determination of sucrose, raffinose and stachyose in legumeseeds. Journal of Food Science, 40 (5): 1087-1088 .

20. Ueda, M; K. Sasaki; K. Inaba and Y. Shimabayashi. 2000. Changes in physical and chemical properties during maturation of mango fruit (Mangifera indica $\mathrm{L}$. Irwin) cultured in a plastic greenhouse. Food Sci Technol Res, 6(4): 299-305.

21. Vayssières, J. F.; Korie, S.; Coulibaly, O.; Temple, L. and Boueyi, S. P. 2008. The mango tree in central and northern Benin: cultivar inventory, yield assessment, infested stages and loss due to fruit flies (Diptera: Tephritidae), Fruits, 63, 33534.

22. Yahia, E. H. M. 1999. Postharvest handling of mango. Technical Report. Agric. Technology Utilisation and Transfer (ATUT). Giza. Egypt. pp. 131. 


\title{
دراسات حقلية ومعملية على إصابة ثمار الماتجو

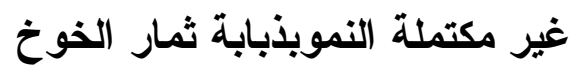

\author{
علي أحمد أمين \\ معهز بحوث وقاية النباتات - مركز البحوث الزراعية - الدقي - جيزة مصر
}

تعتبر ذبابة ثمار الخوخ واحدة من اخطر انواع ذباب الفاكهة على ثمار المانجو في مرحلتي

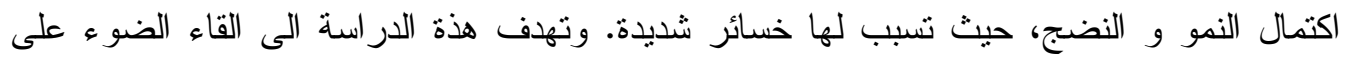
اصابة ثمار المانجو غير مكتملة النمو بذبابة ثمار الخوخ وذلك من خلال التقدير الحقلي وجمع عينات

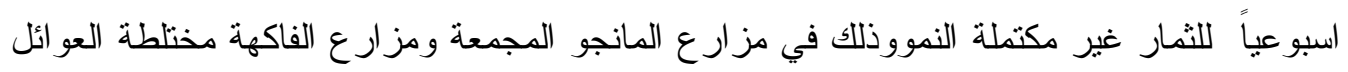

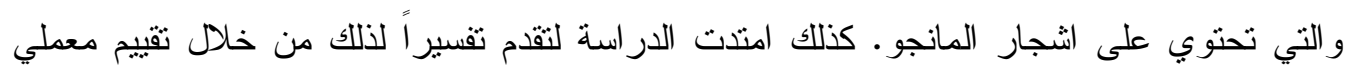

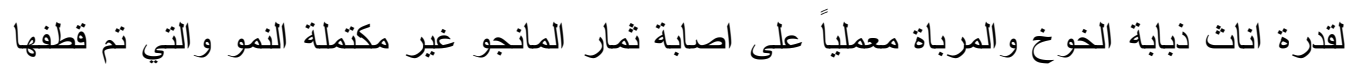
ووضعها تحت درجة حرارة الغرفة لمدة 0 و • و و 1 يوم مقارنة بثمار غير مكتملة النمو حديثة

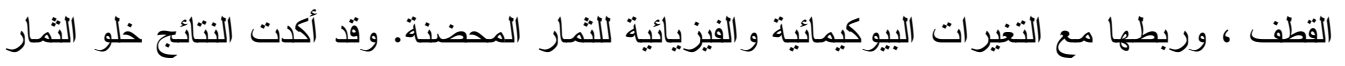

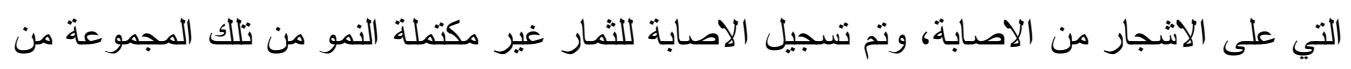

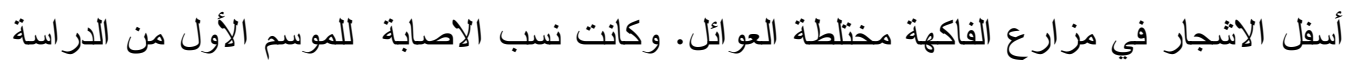

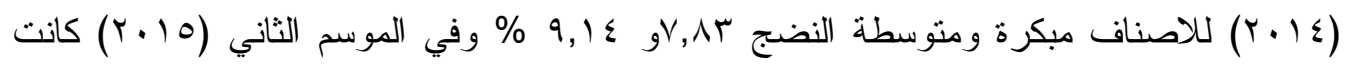

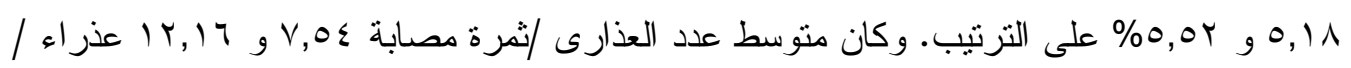

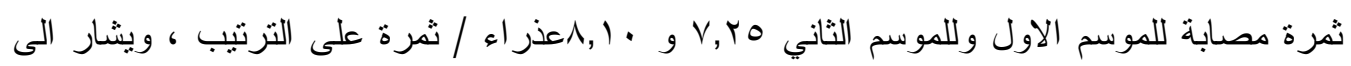

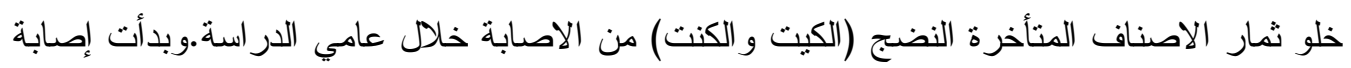

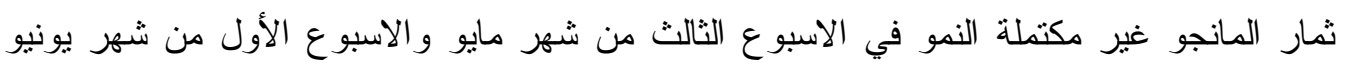

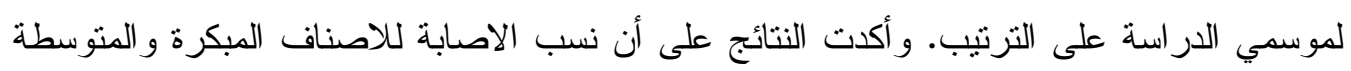

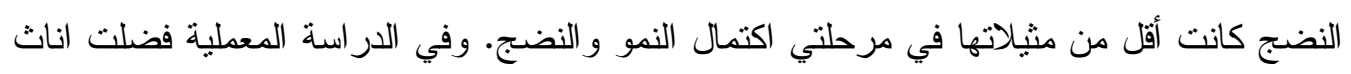

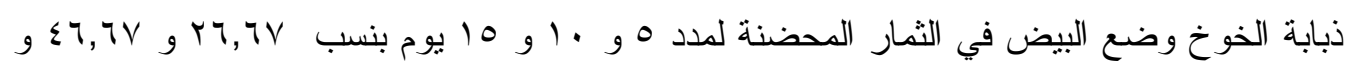

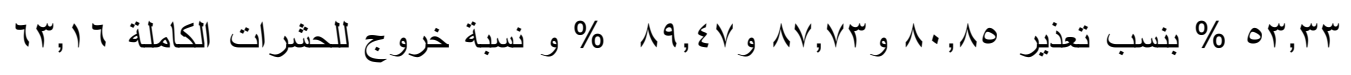

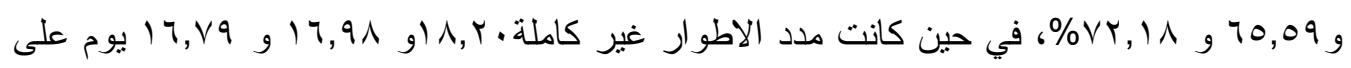
الترتيب. وأكدت الدر اسة المعملية على أن التغير في بعض الصفات الكيماوية و الفيزيائية منل ازدياد

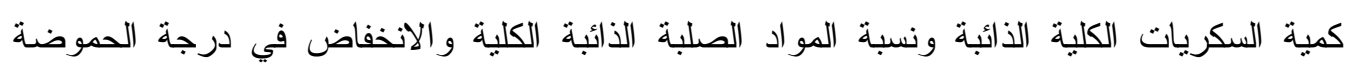

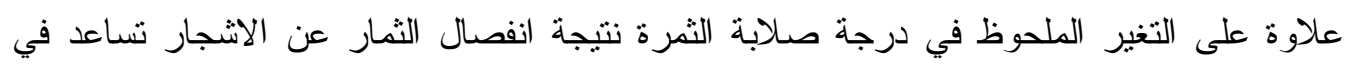

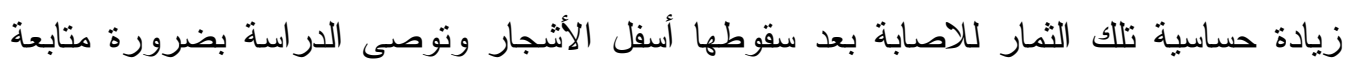

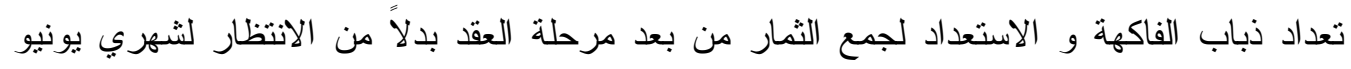

